\title{
Edmodo-Based Blended Learning Model as an Alternative of Science Learning to Motivate and Improve Junior High School Students' Scientific Critical Thinking Skills
}

https://doi.org/10.3991/ijet.v14i07.9980

\author{
Sri Wahyuni \\ Universitas Negeri Surabaya, Surabaya, Indonesia \\ Universitas Jember, Jember, Indonesia \\ I Gusti Made Sanjaya, Erman, Budi Jatmiko ${ }^{(凶)}$ \\ Universitas Negeri Surabaya, Surabaya, Indonesia \\ budijatmiko@unesa.ac.id
}

\begin{abstract}
This study aims to analyze students' scientific critical thinking skills through learning with edmodo-based blended learning models. This study is Pre-Experimental using one group pre-test post-test design involving 35 class VIII students at Public Junior High School 10 Jember, Indonesia. The instruments used were teacher activity observation sheets, student activity observation sheets, scientific critical thinking skills assessment sheets, and student motivation sheets. Before and after learning activity, students are given the same initial test (pre-test) and final test (post-test). The collected data was analyzed by quantitative descriptive analysis. The results of the study show that: (1) students are motivated in classical learning by $78.13 \%$ with motivated criteria. The highest value is on the likes and active indicators using Edmodo, which is equal to $88.47 \%$ and the lowest value on the indicator of activity asks questions and opinions at edmodo, which is equal to $70.93 \%$; and (2) there is an increase in scientific critical thinking skills of students with a mean n-gain of .32 , with the criteria being moderate. The highest value is achieved on the indicator of fact analysis, which is equal to .55 and the lowest value on the indicators of delivery of argumentation, which is equal to .19. The conclusion of this study is that science learning with an edmodo-based blended learning model can motivate learning and improve scientific critical thinking skills of junior high school students.
\end{abstract}

Keywords-Blended Learning, edmodo, motivation, scientific critical thinking skills

\section{Introduction}

Education in Indonesia today is faced with a challenge to produce human resources that have superior competencies and are able to compete in the global era. This is in 
accordance with the 21 st century education development paradigm, where learning outcomes are directed at:

- Critical thinking and problem solving skills, creativity and innovation, and collaboration and communication,

- Skilled at using media, information, technology and communication

(ICT) [1]. Therefore, science learning in the curriculum in Indonesia, namely the 2013 curriculum is designed and directed so that students can fulfill the skills and abilities needed in the 21 st century.

Technology has a major role in building 21 st century skills, so that students 'skills in using students' technology and scientific critical thinking skills are very important to ensure the success of learning [2].

According to Dwyer et al. [3], students who have higher scientific critical thinking skills will get higher learning outcomes compared to students who have lower scientific critical thinking skills. This is because scientific critical thinking is a combination of abilities, knowledge, values, attitudes, skills, and processes. Scientific critical thinking is reasonable and reflective thinking that focuses on deciding what must be trusted or done through observation, analyzing, synthesizing, and concluding. So, someone who already has scientific critical thinking skills, can be said to have been able to use his mind to think abstract levels, be open to everything, and be able to communicate effectively with others [4]. Therefore, scientific critical thinking skills must be used as part of science learning so that the scientific critical thinking process is increasingly honed.

Based on the results of the 2015 Program for International Student Assessment (PISA), Indonesian students are still at level 3 of the 6 levels in PISA, which can only explain a simple context based on scientific knowledge, whereas scientific critical thinking can be used to think complexly. On level 5, which can make explanations based on evidence and arguments based on scientific critical analysis [5]. This, allegedly causing the results of the achievement of science evaluations of Indonesian students in the measurement of scientific critical thinking in the TIMSS (The Trends of the International Mathematics and Science Study) held by the IEA (International Association for the Evaluation of Educational Achievement) was low. 2011 TIMSS results for science and cognitive domains (understanding, application, and reasoning), Indonesian students obtain a 397 grade below the International average grade of 500, meaning that Indonesian students' science knowledge is still in the limited scientific category if given explicit evidence and clear, and not yet have the ability to reason scientifically in compiling explanations based on evidence and argumentation using critical analysis [6]. This happens because the learning process tends to be done using the teacher center model, where lecture activities become the dominance of learning activities so students tend to be passive and do not show a good thought process [7].

The results of the initial study relating to scientific critical thinking skills in the temperature and heat material in 35 class VIII students of MTs Bustanul Ulum Panti, Jember district were in the score range of $53.25-68.42$ on a scale of $0-100$. The average score of the test results of students' scientific critical thinking skills is included in the less category [8]. In the initial study, students were less able to 
formulate problems that were the focus of complex problems. This is in line with the results of the Ulandari et al. [9] in the Public Junior High School 3 of Balung, Jember district, which stated that junior high school students' critical thinking skills, such as; interpretation ability (40.47\%); analysis (31.28\%); synthesis (30.25\%); evaluation (34.45\%); concluded (29.53\%); inference (37.21\%); and explanation (39.53\%). According to Martin [10], the problem of scientific critical thinking skills also occurs in other countries, such as Australia in 2011 which reported that the first two years of learning on campus had $45 \%$ of students not experiencing a significant increase in scientific critical thinking skills and reasoning.

A suitable learning model to help students achieve 21 st century skills is the blended learning model [11]. The blended learning model, also called hybrid learning, is learning that combines face-to-face learning in class with online learning [12]. In the blended learning model, students are required to be able to collaborate, ask questions, and think critically well planned [13]. The application of blended learning is supported by ICT facilities that already exist in schools, such as students who mostly have laptops to access the internet at home through wifi and mobile phones, teachers also have laptops to access the internet, then schools also provide wifi, The use of edmodo as a medium in the blended learning model is an alternative learning that is felt to be very good for improving students' scientific critical thinking skills [16]. This was supported by Fatimah [17] who stated that Edmodo offered a unique opportunity to collaborate among students where they could build collaborative teams so that they could develop students' critical thinking skills. According to Khalel [18] that most students have high motivation for learning because they think that learning to use Edmodo facilitates and increases effective communication of learning and can save time.

Based on the background and problem identification, the objective to be achieved in this study is to increase motivation and scientific critical thinking skills through the application of edmodo-based blended learning models as an alternative to science learning in junior high school.

computer, and projector in learning.Thus, the blended learning model is expected to be able to help students overcome their learning difficulties, and giving them the opportunity to achieve higher scientific critical thinking skills $[14,15]$.

\section{Overview}

\subsection{Blended learning}

Etymologically the term blended learning consists of two words, namely blended and learning. Blended word means mixture or fusion while learning is formed from learned basics that have the meaning of learning [19]. Blended learning as a combination of learning from two historically separate teaching and learning models, namely face-to-face learning systems with online learning systems. Face-to-face learning systems have evolved centuries ago, while online learning began to grow and develop [20]. The application of a learning model must be based on learning theory 
that is suitable for the learning process in accordance with predetermined goals [21]. According to Bonk [22] the characteristics of the blended learning model include, namely:

- Blended learning is a way of delivering information and communication, training, education, both the substance of learning material and the science of education that is carried out online.

- Blended learning does not replace traditional learning models in the classroom, but strengthens the learning model through material enrichment and the development of educational technology.

- Use material that is independent because it can be accessed by teachers and students anywhere and anytime.

\subsection{Edmodo}

Edmodo was developed at the end of 2008 by Nic Borg and Jeff Ohara who argued that it was necessary to develop a school environment that was connected with all activities in the world. The purpose of Edmodo's creation is that there is no gap between the lives of students in school and their daily lives. Edmodo is a social networking media that is safe for students and teachers who refer to Facebook social networks, so this system has features similar to Facebook. In fact, many say Edmodo is a Facebook school, because besides being a social networking media among its users, Edmodo also supports the online learning process [23]. At this site parents can also join and communicate with teachers and parents or guardians of other students, besides that of course with their own sons or daughters so they can find out the activities and results of their children [24]. In the learning process, Edmodo is equipped with several learning activities, such as Quiz, Assignment, Poll and File or Link if needed in a larger or different format, online library, closed group space and giving awards to students.

The advantages of Edmodo according to Daulay [25] include:

- Mmaking learning not dependent on time and place because it can be accessed wherever and whenever

- Alleviating the teacher's task to provide assessment to students

- Provide opportunities for parents / guardians of students to monitor learning activities and achievements of their children

- Make the class more dynamic because it allows teacher and student interaction between students and students in terms of lessons or assignments

- Facilitating multidisciplinary group work

- Encourage collaborative virtual environments that help process-based learning

- Easy to use

- Closed group collaboration, because only those who have a group code can take classes

- Free, accessible online, and available for smartphone devices

- Do not need a server at school 
- Edmodo is always updated by the developer

- Edmodo can be applied in one class, one school, between schools in one city / district

- Edmodo is used to communicate using social media, learning material, evaluation, team teaching, and teacher collaboration.

\subsection{Scientific critical thinking skills}

The ability to think someone has been born since but must be trained at all times, because the ability to think will not be able to develop into a skill without being trained [26]. Therefore, to improve one's ability requires a different training process both in quality and quantity, because each student has different learning abilities, depending on which intelligence is most prominent in him. According to Ennis [27] ideal critical thinkers have at least five abilities, including: basic classification skills, basic abilities for analysis, the ability to make inferences, the ability to make further clarifications, and the ability to make predictions and integration. According to Fisher [28] critical thinking is defined as the ability that is responsible and able to control our own minds. Critical thinking involves various skills such as identifying sources of information, analyzing their credibility, reflecting on whether information is consistent with their previous knowledge, and drawing conclusions based on their critical thinking [29].

So, it can be concluded that critical thinking is reasoned thinking, reflective, responsible for making reliable decisions. A person who thinks critically can ask questions correctly, obtain information that is relevant, effective and creative in selecting and sorting information, logical reasons for information, and conclusions that can be trusted and convincing. Table 1 provide information about indicators of scientific critical thinking skills and operational definitions.

Table 1. Indicators and Operational Definitions of Scientific Critical Thinking Skills

\begin{tabular}{|c|l|l|}
\hline Number & $\begin{array}{c}\text { Indicator of Scientific Critical } \\
\text { Thinking Skills }\end{array}$ & \multicolumn{1}{c|}{ Operational definition } \\
\hline 1 & Fact Analysis (Actual) & $\begin{array}{l}\text { Students are able to analyze the meaning of the facts } \\
\text { presented in the problem correctly and honestly. }\end{array}$ \\
\hline 2 & Submission of Reason (Reason) & $\begin{array}{l}\text { Students are able to organize thoughts and express } \\
\text { reasons clearly, logically or reasonably. }\end{array}$ \\
\hline 3 & Conclusion (Inference) & $\begin{array}{l}\text { Students are able to distinguish between conclusions } \\
\text { based on valid logic and invalid logic. }\end{array}$ \\
\hline 4 & $\begin{array}{l}\text { Submission of Arguments } \\
\text { (Argumentation) }\end{array}$ & $\begin{array}{l}\text { Students are able to refute an argument irrelevant and } \\
\text { deliver relevant arguments. }\end{array}$ \\
\hline 5 & $\begin{array}{l}\text { Presentation of Implications } \\
\text { (Implication) }\end{array}$ & $\begin{array}{l}\text { Students are able to ask a view and question the impli- } \\
\text { cations of a view }\end{array}$ \\
\hline
\end{tabular}

Source : Adoption of Facione [30] 


\section{$3 \quad$ Methodology}

This study uses Pre-Experimental to determine the impact of a treatment on the research subject without a comparison class (control) and to describe whether there is an increase in motivation and scientific critical thinking skills [31]. The study design is One Group Pre-test Post-test Design. The study was conducted on 35 VIIIA students of Public Junior High School 10 Jember in the odd semester of the 2018/2019 academic year, because the school had school-based internet service and wifi installed since 2009 by having an adequate computer laboratory.

The instruments used were teacher activity observation sheets, student activity observation sheets, scientific critical thinking skills assessment sheets, and student motivation sheets. The steps used in the analysis of students' scientific critical thinking skills are as follows:

- Data from the results of the tests of scientific critical thinking skills are calculated on average test scores

- The increase in scientific critical thinking skills that occur before and after learning is calculated by the normalized gain (n-gain) formula with the Meltzer formula [32].

$$
n-\text { gain }=\frac{X m-X n}{100-X n}
$$

Remarks:

$$
\begin{aligned}
& \mathrm{n} \text {-gain }=\text { normalized gain } \\
& \mathrm{Xm}=\text { post-test score } \\
& \mathrm{Xn} \quad=\text { pre-test score }
\end{aligned}
$$

The criteria for $n$-gain level are: a) n-gain $<.3$; low, b) .7> n-gain $\geq .3$; medium, c) $\mathrm{n}$-gain $\geq .7$; high.

The student motivation sheet is used to determine the attitudes, interests and encouragement that exist in students towards the use of edmodo-based blended learning models. This data will be analyzed and the results used to conclude whether student motivation increases during the learning process using the edmodo-based blended learning model. The steps used in the analysis of student learning motivation are as follows:

- Provide an assessment of each aspect of student learning motivation in accordance with predetermined criteria.

- Summing each aspect of student learning motivation.

- Presenting scores for each aspect of student motivation observed using the formula;

$$
P=\frac{m}{M} x 100 \%
$$


Remarks:

$P=$ percentage motivation score achieved by students

$\mathrm{m}=$ score obtained by students (motivation score)

$\mathrm{M}=$ maximum motivation score

The results obtained are interpreted using the criteria in Table 2.

Table 2. Interpretation Criteria for Student Learning Motivation Score

\begin{tabular}{|c|l|}
\hline Percentage of Motivation (\%) & \multicolumn{1}{|c|}{ Motivational criteria } \\
\hline $86 \leq P \leq 100$ & Very motivated \\
\hline $72 \leq P<86$ & Motivated \\
\hline $58 \leq P<72$ & Sufficiently motivated \\
\hline $44 \leq P<58$ & Less motivated \\
\hline $30 \leq P<44$ & Not motivated \\
\hline
\end{tabular}

Source: Sugiyono [32]

\section{$4 \quad$ Finding and Discussion}

The implementation of edmodo-based blended learning models to improve students' motivation and scientific critical thinking skills is shown in Table 3.

The results of scientific critical thinking skills of class VIII students of Public Junior High School 10 Jember are shown in Table 4.

Table 3. The Syntax of the Blended Learning Model for Scientific Critical Thinking Skills

\begin{tabular}{|c|c|c|c|}
\hline Phase & \multicolumn{2}{|c|}{ Learning Activities } & $\begin{array}{c}\text { Indicator of trained } \\
\text { Scientific Critical } \\
\text { Thinking Skills }\end{array}$ \\
\hline \multirow[t]{8}{*}{$\begin{array}{l}\text { Seeking of } \\
\text { Information }\end{array}$} & \multirow{8}{*}{\multicolumn{2}{|c|}{$\begin{array}{l}\text { Teachers deliver learning objectives for students' readiness } \\
\text { to initiate and prepare students in the exploration of relevant } \\
\text { concepts through learning activities face to face (face to } \\
\text { face) in the classroom and online through Edmodo. } \\
\begin{array}{|c|c|} \\
\end{array} \\
\text { Figure 1. Teacher Edmodo's page } \\
\end{array}$}} & \multirow[t]{8}{*}{$\begin{array}{l}\text { - Fact Analysis } \\
\text { (Actual) }\end{array}$} \\
\hline & & & \\
\hline & & & \\
\hline & & & \\
\hline & & & \\
\hline & & & \\
\hline & & & \\
\hline & & & \\
\hline $\begin{array}{l}\text { Acquisition of } \\
\text { Information }\end{array}$ & \multicolumn{2}{|c|}{$\begin{array}{l}\text { The teacher guided the students to work on the Assignment } \\
\text { through edmodo in a group discussion to inventory } \\
\text { information, interpret and elaborate the concepts being } \\
\text { taught face to face (face to face) and online through } \\
\text { edmodo. }\end{array}$} & $\begin{array}{l}\text { - Submission of } \\
\text { Reason (Reason) }\end{array}$ \\
\hline
\end{tabular}




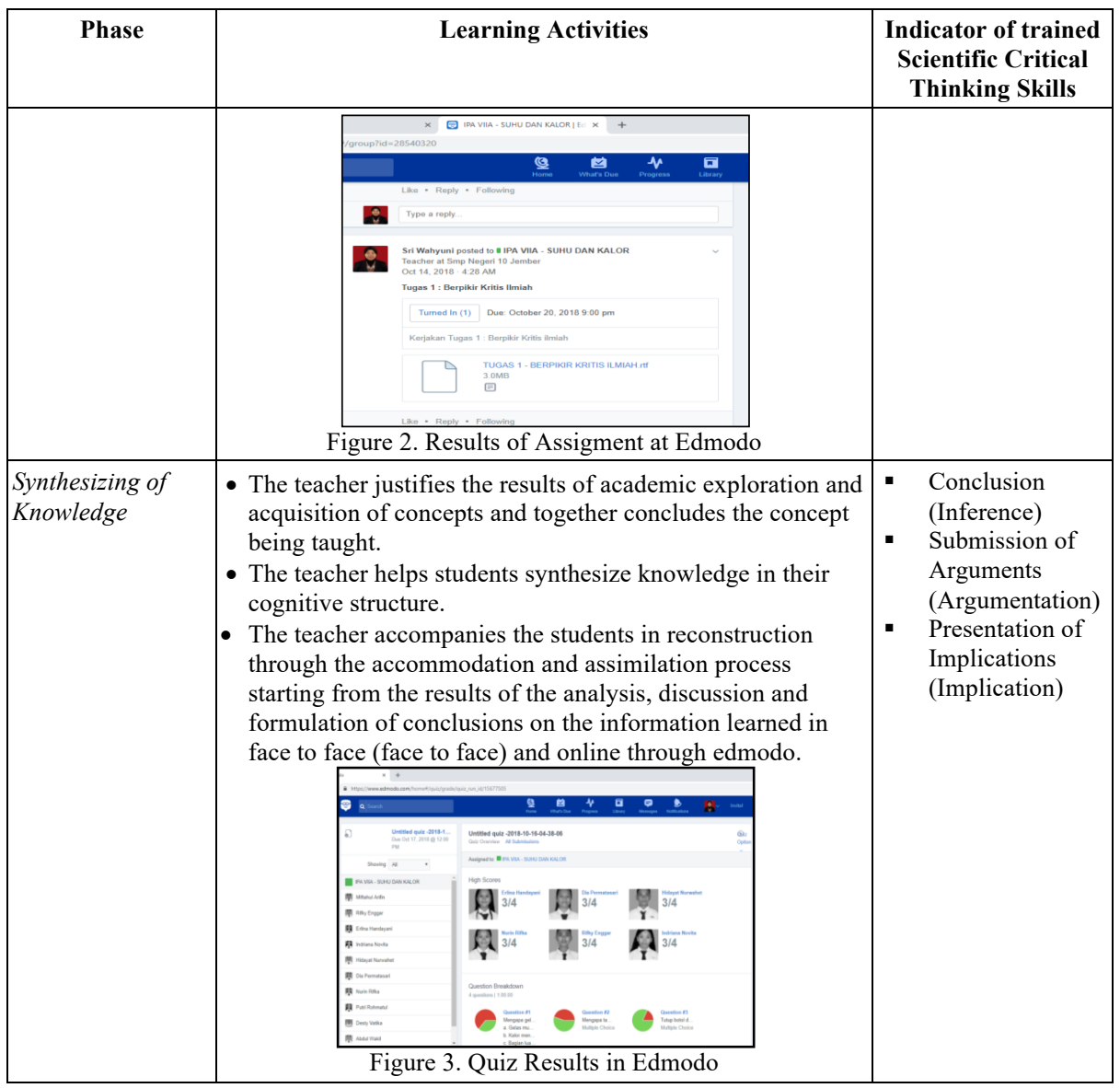

Table 4. Results of Comparison of Pre-test and Post-test Values Each Indicator of Student Scientific Critical Thinking Skills

\begin{tabular}{|c|c|c|c|c|c|}
\hline Indicator & Activity & $\mathbf{N}$ & Mean & n-gain & Criteria \\
\hline Fact Analysis (Actual) & $\begin{array}{l}\text { Pre-test } \\
\text { Post-test }\end{array}$ & $\begin{array}{l}35 \\
35\end{array}$ & $\begin{array}{l}27 \\
53\end{array}$ & .55 & Medium \\
\hline Submission of Reason (Reason) & $\begin{array}{l}\text { Pre-test } \\
\text { Post-test }\end{array}$ & $\begin{array}{l}35 \\
35\end{array}$ & $\begin{array}{l}23 \\
40 \\
\end{array}$ & .28 & Low \\
\hline Conclusion(Inference) & $\begin{array}{l}\text { Pre-test } \\
\text { Post-test }\end{array}$ & $\begin{array}{l}35 \\
35\end{array}$ & $\begin{array}{l}33 \\
53\end{array}$ & .30 & Medium \\
\hline Submission of Arguments (Argumentation) & $\begin{array}{l}\text { Pre-test } \\
\text { Post-test }\end{array}$ & $\begin{array}{l}35 \\
35 \\
\end{array}$ & $\begin{array}{l}20 \\
33 \\
\end{array}$ & .19 & Low \\
\hline Presentation of Implications (Implication) & $\begin{array}{l}\text { Pre-test } \\
\text { Post-test }\end{array}$ & $\begin{array}{l}35 \\
35 \\
\end{array}$ & $\begin{array}{l}13 \\
33 \\
\end{array}$ & .30 & Medium \\
\hline Average n-gain & .32 & Medium & & & \\
\hline
\end{tabular}


Based on the results of the initial analysis of scientific critical thinking skills students' data showed that the average increase in classical critical thinking skills in classical was .32 with the criteria is medium. Students get the highest level n-gain value on the fact analysis indicator which is .55 and get the lowest score on the argument delivery indicator of .19. This is because students are still unable to analyze the process.Students still give responses without being followed by reasons or facts that support the argument. This can be seen from the included facts that are merely copying from the internet and other references. Students use reasoning to only restate the data, the principles of the reasons used are unclear. In the learning activities there is also no interaction between students and other students, such as refuting, supporting or responding to arguments put forward by other students so that reasoning has not developed. Thus it can be said that students' skills in delivering arguments must be trained. This is because argumentation skills are a process of thinking ability that requires time to habituation/practice [33].

Toulmin stated that the quality of argumentation skills was determined by the existence of 3 aspects, namely, claims, evidence, and reasoning [34]. Claim is a statement to answer the problem, evidence is scientific data that supports statements, and reasoning is the reason or justification that connects statements with evidence. The ability of states to claim corresponds to the ability to use supporting data to support the statement of claim. The ability of students to state a claim is also influenced by the student's ability to convey the reason (reasoning). It also correlates with the research of Berland \& Mc Neill [35] stating that most students have difficulty to justify claims and convey reasons (reasoning) by providing evidence supporting claims. Inch, et al. [36] stated that the use of argumentation in science learning is the most important part of developing scientific critical thinking skills. Argumentation is a process used by someone to analyze information about a topic and then the results of the analysis are communicated to others.Learning activities with arguments have implications for better reasoning and evidence use [37].

The application of edmodo-based blended learning model can develop students' scientific critical thinking skills, especially on the fact analysis indicator, which is .55 which gets the highest score. This is consistent with the opinion of Vogel et al. [38] who argues that the availability of online-based learning can provide facilities for students to examine data and evidence based on supporting theories so that they are scientific, compare different perspectives on phenomena or issues- science issues, analyze and synthesize data to form conclusions, and argue according to data collected based on facts. Eskin states that students who have the skills to ask and argue based on facts can construct explanations to generate new knowledge, in which new knowledge can be a new theory, a new way of collecting data, or a new way of interpreting the data in order to improve the critical thinking skills of scientific [39].

The edmodo-based blended learning model turns out to be able to create a pleasant learning environment and motivate students to actively think scientifically. The following data on student motivation can be seen in Table 5 . 
Table 5. Student Learning Motivation Data for Each Aspect

\begin{tabular}{|c|c|c|c|c|}
\hline Number & Aspect & Indicator & $\begin{array}{c}\text { The average } \\
\text { achievement of } \\
\text { each aspect }(\%) \\
\end{array}$ & Criteria \\
\hline 1 & $\begin{array}{l}\text { Students' interest and } \\
\text { attention to learning } \\
\text { activities }\end{array}$ & $\begin{array}{l}\text { Like and actively } \\
\text { use edmodo }\end{array}$ & 88.47 & Very Motivated \\
\hline 2 & $\begin{array}{l}\text { The enthusiasm of } \\
\text { students to carry out } \\
\text { their learning tasks }\end{array}$ & $\begin{array}{l}\text { willingness to do } \\
\text { assignments and } \\
\text { quiz on edmodo }\end{array}$ & 77.35 & Motivated \\
\hline 3 & $\begin{array}{l}\text { Student responsibility } \\
\text { for learning activities }\end{array}$ & $\begin{array}{l}\text { not forget to do } \\
\text { the quiz at Ed- } \\
\text { modo }\end{array}$ & 82.29 & Motivated \\
\hline 4 & $\begin{array}{l}\text { Fun in working on tasks } \\
\text { that are on Edmodo }\end{array}$ & $\begin{array}{l}\text { do assignments } \\
\text { or quiz on edmo- } \\
\text { do }\end{array}$ & 71.62 & $\begin{array}{l}\text { Sufficiently Moti- } \\
\text { vated }\end{array}$ \\
\hline 5 & $\begin{array}{l}\text { The reactions shown by } \\
\text { students to learning } \\
\text { activities }\end{array}$ & $\begin{array}{l}\text { active asking } \\
\text { questions and } \\
\text { opinions on } \\
\text { edmodo }\end{array}$ & 70.93 & $\begin{array}{l}\text { Sufficiently Moti- } \\
\text { vated }\end{array}$ \\
\hline $\begin{array}{c}\text { Overall student } \\
\text { learning motivation }\end{array}$ & 78.13 & Motivated & & \\
\hline
\end{tabular}

Based on the results of the analysis, it is known that classical student learning motivation is $78.13 \%$ with motivated criteria. Students get the highest score on the likes and active indicators using edmodo, which is $88.47 \%$, and get the lowest score on the indicator of activity asking questions and opinions at Edmodo, which is $70.13 \%$. This is in accordance with the results of Anisa and Ratnasari's research [40], which suggest that students will be motivated towards learning if students know what they will learn,can access material first, so that they are better prepared to learn. Learning readiness will increase student participation in the learning process and can construct various knowledge and experiences to describe, analyze, and answer the problems given by the teacher according to their own ways. Constructing the knowledge to explore material has proven to be more effective than traditional methods.

\section{Conclusion}

Based on the results of research and discussion, it can be concluded that science learning with an edmodo-based blended learning model can:

- Motivating students to learn with motivated criteria. The highest value is in the indicator of likes and active using edmodo, which is equal to $88.47 \%$ and the lowest value on the indicator of activity raises questions and opinions in edmodo, which is equal to $70.93 \%$; and

- Improving the scientific critical thinking skills of junior high school students, with an average n-gain of .32, moderate category, the highest value achieved on the indicator of fact analysis, which is equal to .55 and the lowest value on the argument delivery indicator, which is .19. 
Based on the conclusions above, the teacher is advised to achieve the quality of the learning process by using the edmodo-based blended learning model, by making adequate preparations, especially for the connection of internet networks in computer laboratories, so that students can practice students' scientific critical thinking skills to the maximum. In addition, teachers are expected to be able to vary the use of learning resources that can avoid boredom and create a pleasant atmosphere.

\section{Acknowledgement}

The author's gratitude goes to the Ministry of Research, Technology and Higher Education for funding the Research. Likewise, the author's gratitude goes to Universitas Jember and Universitas Negeri Surabaya that have provided research opportunities.

\section{$7 \quad$ References}

[1] Fadlillah. (2014). Implementation of 2013 Curriculum. Yogyakarta: AR-RUZZ MEDIA.

[2] Alfonso, D, V. (2015). Evidence of Critical Thinking in High School Humanities Classroom. Journal of Gist Education and Learning Research, 11, pp 26-44. https://doi.org/10.2 $\underline{6817 / 16925777.281}$

[3] Dwyer, C. P., Hogan, M. J., \& Stewart School, I. (2014). An integrated critical thinking framework for the 21st century. Thinking Skills and Creativity, 12 (2012), pp 43-52. https://doi.org/10.1016/j.tsc.2013.12.004

[4] Facione, P.A. (2015). Critical Thinking: What it Is and Why It Counts. Insight Assessment. California: California Academic Press.

[5] OECD. (2014). PISA 2012 Results: What Students Know and Can Do - Student Performance in Mathematics, Reading and Science (Volume I, Revised edition, February 2014), PISA, OECD Publishing.

[6] TIMSS \& PIRLS International Study Center. (2012). TIMSS 2011 international results in science. Retrieved Desember 15, 2014, from Boston: The TIMSS \& PIRLS International Study Center, Boston College. http://timss.bc.edu/timss2011/release.html.

[7] Ellianawati. (2012). Development of Self Regulated Learning Mathematics Physics Teaching Materials as an Effort to Improve Self-Study Ability. Jurnal Pendidikan Fisika Indonesia, 8 (2012): 33-40.

[8] Wahyuni, S. (2015). Developing science learning instruments based on Local wisdom to improve student's critical Thinking Skills. Jurnal Pendidikan Fisika Indonesia, 11(2): 156-161.

[9] Ulandari, F.S, Wahyuni, S, Bachtiar, R.W., (2018). Development of scientific-based modules to train critical thinking skills in motion material. Jurnal Pembelajaran Fisika, Vol. 7 No. 1: 15-21. https://doi.org/10.19184/jpf.v7i1.7220

[10] Martin, M. O., Mullis, I. V., Foy, P., dan Stanco, G. M. (2012). TIMSS 2011 International Science Report. Boston: TIMSS and PIRLS International study.

[11] Tham, K \& Tham, C. (2011). Blended Learning - a Focus Study on Asia. IJCSI International Journal of Computer Science Issues, Volume 8 (Issue 2): 136-142.

[12] Nani, S. \& Mulyono, H. (2017). A Hybrid Classroom Instruction in Second Language Teacher Education (SLTE): A Critical Reflection of Teacher Educators. iJET (Internation- 
al Journal of Emerging Technologies in Leraning), Vol. 12, No. 5, pp 169-180. https://doi.org/10.3991/ijet.v12i05.6989

[13] A. S. Kestha,. \& I. I. Harb. (2013). The Effectiveness of a Blended Learning Program on Developing Palestinian Tenth Graders' English Writing Skills. Educational Journal. Vol. 2, No. 6, pp 208 - 221. https://doi.org/10.11648/j.edu.20130206.12

[14] Popil, I. (2011). Promotion of critical thinking by using case studies as teaching method. Nurse Education Today, 31 (2011): 204-207. https://doi.org/10.1016/j.nedt.2010.06.002

[15] Hyytinen, H., Nissinen, K., Ursin, J., Toom, A., \& Lindblom-Ylänne, S. (2015). Problematising the equivalence of the test results of performance-based critical thinking tests for undergraduate students. Studies in Educational Evaluation, 44: 1-8. https://oi.org/10.1 016/j.stueduc.2014.11.001

[16] Kustandi, Cecep. (2017). E-Learning Effectiveness Based on Edmodo and Schoology on Students' Critical Thinking Ability. Jurnal Educate, Vol 2. No 1: 1-9.

[17] Fatimah, Al-Kathiri. (2014). Beyond the Classroom Walls: Edmodo in Saudi Secendary School EFL Instruction, Attitudes and Challenges. English Language Teaching, Vol. 8 No 1.

[18] Khaleel, Al-Said. (2015). Students Perceptions of Edmodo amd Mobile Learning and Their Real Barriers Toward Thjem. TOJET: The Turkish Online Journal Of Education Technology. Vol 14. No 2.

[19] Bersin, J. (2004). The blended learning book. San Fransisco: Pleiffer.

[20] Suana, W. N. Maharta, I D. P. Nyeneng, Wahyuni, S. (2017). Design and Implementation of Schoology based Blended Learning Media for Basic Physics 1 Course. Jurnal Pendidikan IPA Indonesia, 6 (1): 170-178.

[21] Banyen, W. Viriyavejakul, C and Ratanaolarn, T. (2016). A Blended Learning Model for Learning Achievement Enhancement of Thai Undergraduate Students. iJET (International Journal of Emerging Technologies in Learning), Vol. 11, No. 4, pp 4855.https://doi.org/10.3991/ijet.v11i04.5325

[22] Bonk, C. J., \& Graham, C. R. (Eds.). (2005). Handbook of blended learning: global perspectives, local designs. San Francisco: Pfeiffer Publishing.

[23] Hursen, C. \& Fasli, F. G. (2017). The Impact of Reflective Teaching Applications Supported by Edmodo on Perspective Teachers' Self Directed Teaching Learning Skills. iJET (International Journal of Emerging Technologies in Learning), Vol. 12, No. 10, pp 21-34.

[24] Wichadee, S. (2017). A Development of the Blended Learning Model Using Edmodo for Maximizing Students' Oral Proficiency and Motivation. iJET (International Journal of Emerging Technologies in Learning), Vol. 12, No. 2, pp 137-154. https://doi.org/10. 3991/ijet.v12i02.6324

[25] Daulay, Utami Alam dkk,. (2016). The Effect of Blended Learning Based on Edmodo and Learning Motivation on Biology Learning Outcomes and Student Retention in the Human Circulatory System in Class VIII SMP Negeri 5 Medan. Jurnal Pendidikan Biologi. 6, (1). pp 260-266.

[26] Husamah. (2015). Thinking Skills for Environmental Sustainability Perspesctive of New Students for Biology Education Department through Blended Project Based Learning Model. Indonesian Journal of Scince Education, Vol. 4 (2): 110-119.

[27] Ennis, R.H. (2011). The Nature of Critical Thinking: An Outline of Critical Thinking Dispositions and Abilities. Illinois: University of Illinois.

[28] Fisher, A. (2009). Critical Thinking: An Introduction. Jakarta: Erlangga.

[29] Jatmiko, B., Prahani, B. K., Munasir,, Supardi, I. Z. A., Wicaksono, I., Erlina, N., Pandiangan, P., (2018). The Comparison of OR_IPA Teaching Model and Problem Based 
Learning Model Effectiveness to improve Critical Thinking of Pre-Service Physics. Journal of Baltic Science Education, Vol. 17, No. 2: 300-309.

[30] Facione, P. A., \& Facione N. C. (2011). The California Critical Thinking Skills Test-test manual. Millbrae, California: California Academic.

[31] Arikunto, S. (2010). Research Procedure: A Practice Approach. Jakarta: Rineka Cipta.

[32] Meltzer, D.E. (2002). The Relationship between Mathematics Preparation and Conceptual Learning Gain in Physics: A Possible "Hidden Variable" in Diagnostics_Pretest Scores. American Journal of Physics. Vol. 70 (12): 1259-1268. https://doi.org/10.1119/1.1514215

[33] Sugiyono. (2014). Educational Research Methods. Bandung: Alfabeta.

[34] Dawson, V., \& Venville, G. J. (2009). High-school student' informal reasoning and argumentation about biotechnology: An indicator of scientific literacy? International Journal of Science Education. 31, (11): 1421-1445.

[35] Erduran, S., \& Jimenez-Aleixandre, M.P. (2008). Argumenation in Science Education. Florida State University-USA: Spinger.

[36] Berland, L.K. (2010). Understanding the composite practice that form when classroom take up the practice of scientific argumentation. Doctoral dissertation at The Graduate School of Northwestern University: unpublished.

[37] Inch, E. S. et al. (2006). Critical Thinking and Communication: The use of reason in argument. 5th Ed. Boston: Pearson Education, Inc.

[38] Vogel, B. et al. (2010). Integrating Mobile, Web and Sensory Technologies to Support Inquiry-Based Science Learning, Presented at The 6th IEEE International Conference on Wireless, Mobile, and Ubiquitous Technologies in Education.

[39] Wardani, A.D., Yuliati, L., \& Taufik, A. (2016). Ability of Scientific Argumentation and Solving Physics Problems of High School Students in Style and Motion Material. Prosiding Seminar Pendidikan IPA Pascasarjana UM, 1: 223-231.

[40] Anisa, A.A., \& Ratnasari, A. (2013). Blended Learning: Improving Motivation in Learning Accounting Case of SMKN 1 Bantul 2012/2013. Jurnal Pendelikon Akuntansi Indonesia. 6 (1): 155-159. https://doi.org/10.21831/jpai.v11i1.1685

\section{Authors}

Sri Wahyuni was a Lecturer, Researcher, at Universities Jember, Jl. Kalimantan III no 37 Jember 68121, Indonesia. She is now a Doctoral student at Universities Negeri Surabaya, Jl. Ketintang Surabaya 60231, Indonesia. (e-mail: sriwahyuni.fkip@unej.ac.id).

I Gusti Made Sanjaya. Doctor, Researcher, Universities Negeri Surabaya, Jl. Ketintang Surabaya 60231, Indonesia. (E-mail: igmasanjaya@unesa.ac.id).

Erman. Doctor, Researcher, Universities Negeri Surabaya, Jl. Ketintang Surabaya 60231, Indonesia. (E-mail: erman@unesa.ac.id).

Budi Jatmiko. Professor, Researcher, Universitas Negeri Surabaya, Jl. Ketintang Surabaya 60231, Indonesia.(budijatmiko@unesa.ac.id, bjbjatmiko2@gmail.com).

Article submitted 2018-12-07. Resubmitted 2019-01-15. Final acceptance 2019-01-17. Final version published as submitted by the authors. 